\title{
Recurrent central catheter complications in a newborn: can we blame neonatal lupus?
}

\author{
Catarina Franco, ${ }^{1,2}$ Fabiana Fortunato, ${ }^{3}$ Ana Teresa Maria, ${ }^{4}$ Monica Marçal ${ }^{1}$
}

${ }^{1}$ Neonatal Intensive Care Unit, Centro Hospitalar de Lisboa Ocidental, Lisbon, Portugal ${ }^{2}$ Department of Pediatrics, Hospital of Divino Espírito Santo of Ponta Delgada, Ponta Delgada, Portugal ${ }^{3}$ Department of Pediatrics, Hospital de Caldas da Rainha, Caldas da Rainha, Portugal ${ }^{4}$ Department of Paediatrics, Hospital de Cascais, Cascais, Portugal

Correspondence to Dr Catarina Franco, catmoraisfranco@gmail.com

Accepted 25 January 2018
Check for updates

To cite: Franco C,
Fortunato F, Maria AT, et al.
BMJ Case Rep Published
Online First: [please
include Day Month Year].
doi:10.1136/bcr-2017-
223676

\section{DESCRIPTION}

We present the case of a preterm newborn, whose mother had medical history of systemic lupus erythematosus and antiphospholipid syndrome treated in pregnancy with enoxaparin, prednisolone, azathioprine and hidroxicloroquine. Routine ultrasonography at 28 weeks of gestation revealed cerebral artery blood flow changes and cerebral ventricular dilatation in the fetus. Elective caesarean section was performed at 28 weeks and 4 days of gestational age.

In the neonatal intensive care unit, the newborn developed central catheter complications in four distinct situations.

First, loss of right femoral pulse after the removal of a central arterial umbilical catheter was noticed. Doppler ultrasonography documented turbulence in the ipsilateral iliac artery.

Afterwards, obstruction and local inflammatory signs recurrently appeared after the insertion of three different polyurethane epicutaneo-cava catheters, with visible erythematous trajectory of the catheter and local oedema (figure 1). Clinical signs disappeared shortly after removal of each device, and the patient became asymptomatic.

Infection was excluded in all four events. Aetiological investigation showed strongly positive (>640 UA $/ \mathrm{mL}$ ) anti-SSA antibodies Ro60 and Ro52, which are the hallmark laboratory tests for neonatal lupus (NL). Antiphospholipid antibodies were negative.

Transitory anaemia and thrombocytopaenia were present in the first days of life. Echocardiogram was normal, with no evidence of NL cardiac manifestations. Cerebral transfontanelar ultrasound was regularly performed, showing signs of cerebral ventricular dilatation, subarachnoid haemorrhage and increased periventricular white matter echogenicity. These features gradually regressed, with no complications.

The patient was discharged at 39 weeks and 6 days postmenstrual age and maintains a regular follow-up to monitor possible late manifestations of NL and other morbidities related to prematurity. The patient is now 6 months of age, and until this date, no other manifestations of NL were found.

$\mathrm{NL}$ is caused by the transplacental passage of maternal antibodies, mainly anti-Ro/SSA, anti-LA/ SSB. $^{1-3}$

These autoantibodies can target neonatal tissues and can cause mainly cutaneous, cardiac and haematological disorders. Congenital heart block is the most serious complication, and it can

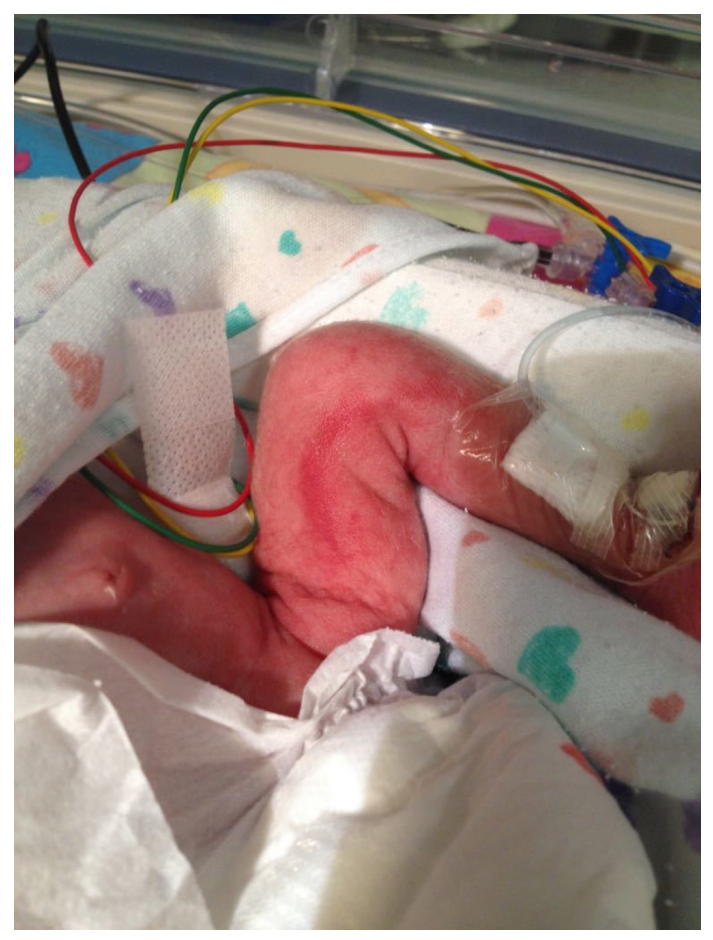

Figure 1 Inflammatory signs in peripherally inserted polyurethane epicutaneo-cava catheter trajectory.

appear during pregnancy or after birth. ${ }^{1-3}$ Also, some infants may manifest haematological, neurological and hepatobiliary abnormalities. ${ }^{1-3}$ Less commonly, vascular events such as central nervous system vasculopathy have been documented. ${ }^{2}$ The disease can present itself in numerous other ways, some of them atypical forms of already known manifestations. ${ }^{2}$ It is crucial to maintain follow-up, since some manifestations can have a late presentation. ${ }^{3}$

This case reports a recurrent vascular inflammatory reaction in a newborn with documented NL which, to our knowledge, has not yet been described in the literature. Also, the patient had haematological and neurological features that have already been described in patients with NL, although it might also be related with prematurity.

The authors hypothesise a possible pathophysiological association between the passage of maternal autoantibodies and the described vascular events, although caution is needed in establishing causality.

Since the range of NL presentation is expanding, ${ }^{3}$ reporting similar cases could bring more insight into a potential association between these events and the underlying condition. 


\section{Learning points}

Although infections are one of the most common causes for catheter dysfunction, other aetiologies should be taken into account.

- Neonatal lupus (NL) is a rare entity that should raise awareness to diverse types of manifestations when a clinical suspicion exists.

- The majority of the disorders related with NL are transient, although monitoring these patients for possible late manifestations is mandatory.

Contributors All authors contributed to the manuscript as follows: CF and MM: conception and manuscript redaction. FF and ATM: critical manuscript revision. All authors contributed to the refinement and approved the final manuscript.

Competing interests None declared.

Patient consent Guardian consent obtained.

Provenance and peer review Not commissioned; externally peer reviewed.

(c) BMJ Publishing Group Ltd (unless otherwise stated in the text of the article)

2018. All rights reserved. No commercial use is permitted unless otherwise expressly granted.

\section{REFERENCES}

1 Johnson B. Overview of neonatal lupus. J Pediatr Health Care 2014;28:331-41.

2 Morais S, Santos IC, Pereira DF, et al. Neonatal lupus with atypical cardiac and cutaneous manifestation. BMJ Case Rep 2013;2013:bcr2013009249.

3 Zuppa AA, Riccardi R, Frezza S, et al. Neonatal lupus: follow-up in infants with antiSSA/Ro antibodies and review of the literature. Autoimmun Rev 2017;16:427-32.

Copyright 2018 BMJ Publishing Group. All rights reserved. For permission to reuse any of this content visit http://group.bmj.com/group/rights-licensing/permissions.

BMJ Case Report Fellows may re-use this article for personal use and teaching without any further permission.

Become a Fellow of BMJ Case Reports today and you can:

- Submit as many cases as you like

Enjoy fast sympathetic peer review and rapid publication of accepted articles

- Access all the published articles

Re-use any of the published material for personal use and teaching without further permission

For information on Institutional Fellowships contact consortiasales@bmjgroup.com

Visit casereports.bmj.com for more articles like this and to become a Fellow 